Helgoländer wiss. Meeresunters. 32, 453-465 (1979)

\title{
Moderate predation on meiofauna by the macrobenthos of the Wadden Sea*
}

\author{
K. REISE \\ II. Zoologisches Institut der Universität Göttingen; \\ D-3400 Göttingen, Federal Republic of Germany, \\ and \\ Biologische Anstalt Helgoland (Litoralstation); \\ D-2282 List/Sylt, Federal Republic of Germany
}

\begin{abstract}
The role of meiofauna in the trophic web of marine ecosystems is a controversial topic. During an experimental study on tidal flats in the eastern part of the North Sea, potential predators on meiofauna were kept in enclosures. A gobiid fish, shrimp, crabs, an amphipod, four polychaete worms and a nemertine were tested for their ability to decimate nematodes, turbellarians, ostracods and benthic copepods. Only few macrobenthic species preyed heavily on permanent meiofauna: juveniles of the shore crab Carcinus maenas, the hermit crab Pagurus bernbardus with the colonial hydrozoan Hydractinia echinata on its shells, and the rag worm Nereis diversicolor. When benthic infauna was protected from these predators with exclosures, juvenile macrofauna responded with a marked increase in number, while the permanent meiofauna remained unaltered except for a limited increase in nematodes. It is concluded that in the Wadden Sea abundance of permanent meiofauna (Nematoda, Turbellaria, Ostracoda, Copepoda) is only locally or temporarily regulated by macrobenthic predators.
\end{abstract}

\section{INTRODUCTION}

Meiofauna in the Wadden Sea comprises more than 1000 species, which is numerically about 5 times that of benthic macrofauna; these species are difficult to identify and most tedious to collect. Thus, meiobenthologists have a cumbersome task and evidence that these organisms are of outstanding scientific importance would be a just reward. Hence, the question is posed: Do the vast individual numbers of meiofauna contribute significantly to the trophic web of the marine ecosystem?

Smidt (1951) assumed meiofauna to be of great nutritional value to juvenile fish in the Danish Wadden Sea. McIntyre (1969) regarded predation pressure on meiofauna to be comparatively small and suggested that in sandy areas a substantial portion of the meiofauna production directly supports the decomposer cycle. For a generalized subtidal bottom Gerlach (1978) estimated a meiofaunal contribution of $30 \%$ to the living biomass in the sediment, and assumed that meiofauna makes up a similar percentage in the food of

\footnotetext{
* I acknowledge a grant from the Deutsche Forschungsgemeinschaft (DFG).
} 
the deposit-feeding macrofauna. These three different propositions on the nutritional value of meiofauna to macrofauna can be characterized as "indispensable", "negligible", and "moderate", respectively.

Muus (1967), Elmgren (1976) and Bell \& Coull (1978) have considered the meiofaunal position in the trophic web. They hold that meiobenthos is "grazed down", "limited" or "regulated" by macrobenthic predators.

The present experiments were conducted in the northern Wadden Sea near the island of Sylt, (1) to determine which species actually prey on meiofauna in the presence of alternative food, and (2) to estimate the intensity of macrobenthic predation on meiofauna. It was found that nematodes, turbellarians, ostracods and benthic copepods are inferior prey when compared with juvenile stages of the macrofauna and that regulation of abundance by macrobenthic predators is restricted to local and temporary events.

\section{STUDY AREA AND METHODS}

Königshafen is a sheltered bay, located near the North Sea island of Sylt, and is part of the northern Wadden Sea. Tidal range is $1.7 \mathrm{~m}$ and salinity remains close to $31 \% \mathrm{~S}$. Physical factors and faunal characteristics have been outlined by Wohlenberg (1937) and Reise (1978). The experimental site is a sandy lugworm flat positioned at mid-tide level. The composition of meiofauna has been described by Reise \& Ax (1979), and that of macrofauna by Reise (1978). The sediment is weakly sorted by currents and $67 \%$ of particles are $>500 \mu \mathrm{m}$ in diameter, due to motile sand dunes which invaded the bay in the

\section{Table 1}

Meiofauna within cages after six periods of tidal submergence compared to a control site in the lugworm flat. Mean and standard error refer to six $1 \mathrm{~cm}^{3}$ samples. An asterisk denotes a significantly higher mean according to the independent homogeneity test of Kolmogoroff \& Smirnoff ( $5 \%$ level). Small cage $=83 \mathrm{~cm}^{2}$ and large cage $=280 \mathrm{~cm}^{2}$ cross section, $\mathrm{p}$-meiofauna $=$ permanent meiofauna. Ostracods immigrate into cages while copepods tend to emigrate

\begin{tabular}{|lcccccccc|}
\hline Taxa & \multicolumn{3}{c}{3.8 .1977} \\
Flat & $\begin{array}{c}\text { Small } \\
\text { cage }\end{array}$ & Flat & $\begin{array}{c}\text { 16. 8. 1977 } \\
\text { Small } \\
\text { cage }\end{array}$ & $\begin{array}{c}\text { Large } \\
\text { cage }\end{array}$ & Flat & $\begin{array}{c}\text { Large } \\
\text { cage }\end{array}$ \\
\hline Nematoda & \multicolumn{7}{c}{ Individuals cm-2 } \\
& 34.0 & 41.7 & 43.2 & 69.2 & 43.5 & 57.2 & 46.0 \\
Turbellaria & \pm 7.9 & \pm 17.1 & \pm 20.6 & \pm 30.5 & \pm 10.3 & \pm 6.4 & \pm 17.1 \\
& 2.5 & 5.8 & 1.5 & 1.7 & 2.0 & 3.2 & 4.3 \\
Ostracoda & \pm 2.1 & \pm 4.4 & \pm 1.4 & \pm 0.8 & \pm 1.8 & \pm 2.8 & \pm 3.1 \\
& 2.3 & 9.7 & 3.7 & 4.5 & 9.0 & 4.8 & 9.8 \\
Copepoda & \pm 2.7 & $\pm 5.3^{*}$ & \pm 1.9 & \pm 1.9 & $\pm 4.3^{* *}$ & \pm 2.3 & $\pm 4.7^{*}$ \\
& 12.8 & 7.8 & 4.3 & 1.3 & 1.3 & 4.3 & 3.2 \\
p-meiofauna & \pm 5.2 & \pm 8.6 & $\pm 2.1^{*}$ & \pm 1.2 & \pm 1.0 & \pm 1.9 & \pm 2.7 \\
& 52.2 & 65.2 & 53.7 & 77.2 & 47.0 & 69.7 & 65.3 \\
& \pm 13.7 & \pm 31.3 & \pm 23.6 & \pm 30.4 & \pm 11.0 & \pm 9.1 & \pm 23.7 \\
\hline
\end{tabular}




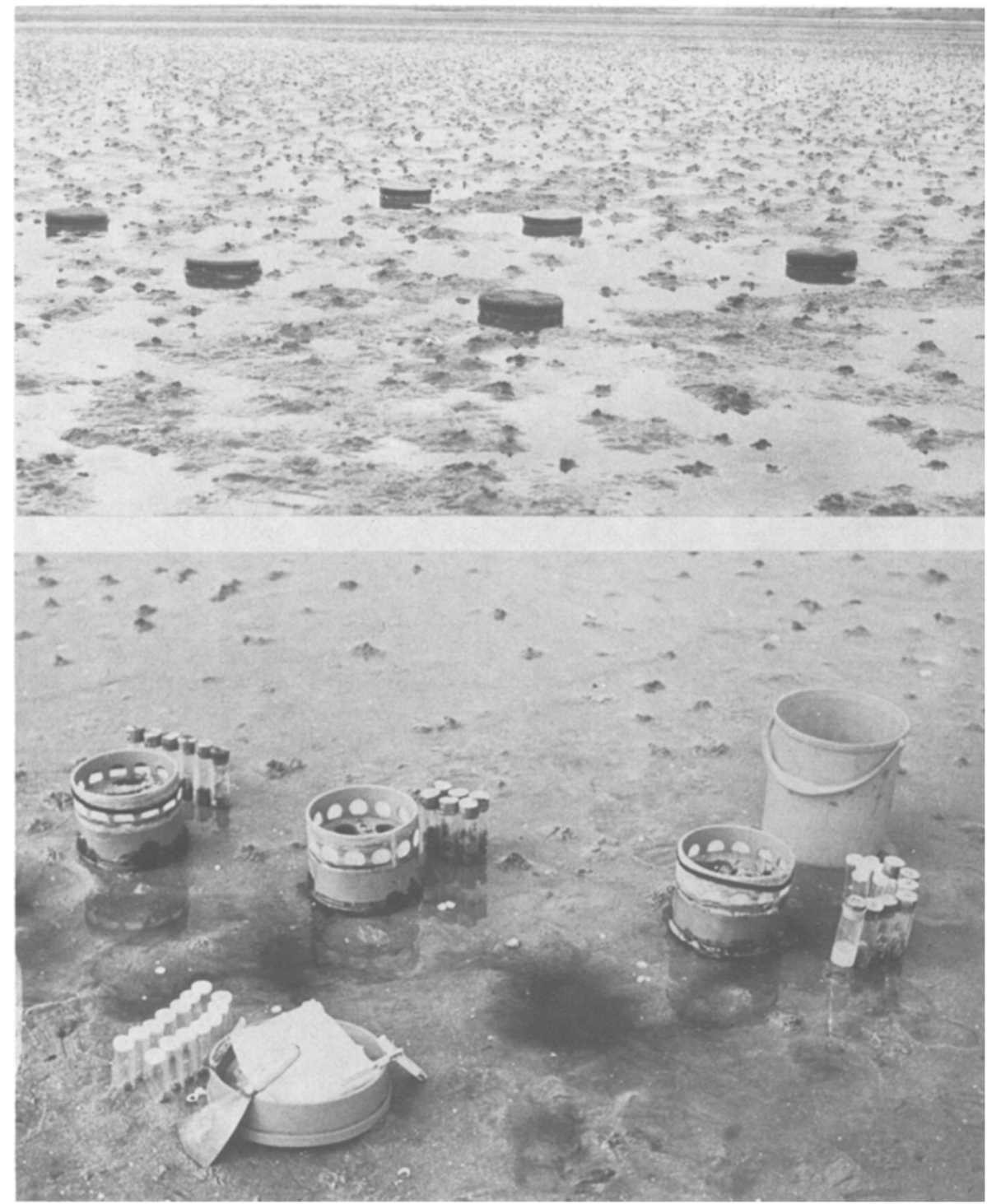

Fig. 1: Cages to enclose or exclude predators from meiofauna in a lugworm flat, in experimental position (above) and dug up for final sampling (below)

past. An experiment with hermit crabs was carried out some distance away at low water mark on a similar flat, slightly richer in detritus and with abundant shell gravei.

Cages to control predator numbers were constructed out of PVC tubes, punched with a row of lateral holes, $34 \mathrm{~mm}$ in diameter. The holes, top and bottom, were covered with $40-\mu \mathrm{m}$ mesh gauze (Fig. 1). Cages were carefully filled with sediment core to the row of 
lateral holes. They were then buried to the level of the inner sediment core and closed with gauze. In some early experiments, cages were small $\left(83 \mathrm{~cm}^{2}\right.$ cross section and $8 \mathrm{~cm}$ height), but mostly large cages $\left(280 \mathrm{~cm}^{2}\right.$ cross section and $15 \mathrm{~cm}$ height) were used. These were buried $10 \mathrm{~cm}$ into the sediment to place the lateral gauze-covered holes at the sedimentwater interface (see Fig. 1). Cages enclosing predators and the corresponding controls remained on the flat for periods of six tidal cycles.

The cages caused changes in meiofaunal abundance when compared with the uncaged flat (Table 1). This was more pronounced in the small than in the large cages. Ostracods seem to invade the cages through the $40 \mu \mathrm{m}$ mesh gauze, while copepods pass the gauze in the opposite direction. Thus, in the predator inclusion experiments comparisons were restricted to cage controls only.

An experiment to evaluate predation pressure on meiofauna exerted by macrofauna was done with a set of six cages: (1) closed with $40 \mu \mathrm{m}$ gauze: all predators excluded; exchange with the surrounding environment was possible to some mobile meiofauna only; (2) closed with $1 \mathrm{~mm}$ gauze: all large predators excluded, unhumpered exchange possible to all meiofauna and small or juvenile macrofauna; (3) closed with $40 \mu \mathrm{m}$ gauze and stocked with juvenile Crangon crangon; (4) closed with $1 \mathrm{~mm}$ gauze and stocked with juvenile Carcinus maenas; (5) the top covered with $40 \mu \mathrm{m}$ gauze and all lateral holes remained open; (6) the top covered with $1 \mathrm{~mm}$ gauze and all lateral holes remained open. In addition, two plots of cage size were selected as unaltered control sites. The experiment lasted 64 days.

Conventionally, the meiofauna of marine soft bottoms is defined as all Metazoa which pass through a $500 \mu \mathrm{m}$ sieve. Animals retained by such a sieve belong to the macrofauna. Taxa with all life stages confined to the lower size category are called permanent meiofauna, set apart from the temporary meiofauna which is composed of juvenile macrofauna (McIntyre, 1969). In this study, permanent meiofauna includes Nematoda, Gastrotricha, Rotatoria, Turbellaria, Gnathostomulida, Hydrozoa, Tardigrada, Halacarida, Ostracoda, benthic Copepoda, and the interstitial polychaete Microphthalmus sczelkowii Mecznikow. Most juveniles of macrofauna are considerably larger than individuals of these taxa and are retained by a $250 \mu \mathrm{m}$ sieve. Thus, this mesh size was found to be ecologically more meaningful than the conventional $500 \mu \mathrm{m}$ sieve which is passed by one part of the juvenile populations while the other is retained. Unlike other studies on meiofauna, the method adopted brings the small oligochaete Paranais litoralis (Müller) into the group of "juvenile macrofauna".

The following sampling procedure was adopted: (1) 6 samples of $1 \mathrm{~cm}^{3}$ (sediment depth $0-1 \mathrm{~cm}$ ) were taken with a glass tube from each cage out in the field. They were washed in a glass beaker and fractioned into 8-12 petri dishes. Meiofauna was picked out with a pipette under a dissecting microscope. Neither sieve nor narcotics were applied. Sampling was restricted to the upper $0-1 \mathrm{~cm}$ layer since during summer it contained more than $75 \%$ of all meiofauna and predation is expected to centre on the layer of highest individual density. (2) 6 samples of $10 \mathrm{~cm}^{2}$ (sediment depth $0-2 \mathrm{~cm}$ ) were washed through a $250 \mu \mathrm{m}$ mesh gauze to obtain small and juvenile macrofauna. (3) Subsequently, all the remaining sediment within the cage was passed through a $1 \mathrm{~mm}$ sieve to count predators and other large macrofauna.

Comparisons between predator cages and control cages were confined to single cages each time. The independent homogeneity test of Kolmogoroff \& Smirnoff (cf. Sachs, 1971) 
was applied to detect differences between sample means drawn from a pair of cages. A mean significantly higher $(5 \%$ level indicated by * in the following tables) than those from the corresponding cage(s) proves a difference in faunal abundance of the sites compared but does not prove significant predation per se. Therefore, statistical treatment is not further extended because the qualitative question, preyed upon or not, has still to be answered by evaluating the composite changes in all the different taxa examined, and these do not represent numerical equivalents.

\section{RESUL'TS}

Eleven macrobenthic species of the Wadden Sea have been tested in enclosures for their ability to prey on meiofauna. The following animals were selected: four polychaetes,

Table 2

Enclosure experiment with small cages: 50 Gammarus locusta, 15.-18. 8. 1977, had no effect on meiofauna; 32 Anaitides mucosa, 30. 7.-3. 8. 1977, did not prey on meiofauna but decimated juvenile hydrobiids

\begin{tabular}{|c|c|c|c|c|c|c|c|}
\hline Taxa/Species & $\begin{array}{r}\text { Gad } \\
\text { lo } \\
\end{array}$ & $\begin{array}{l}\text { marus } \\
\text { custa }\end{array}$ & Control & & $\begin{array}{l}\text { itides } \\
\text { cosa }\end{array}$ & \multicolumn{2}{|c|}{ Control } \\
\hline \multicolumn{8}{|c|}{ Individuals $\mathrm{cm}^{-2}$} \\
\hline Nematoda & 40.5 & \pm 13.1 & $69.7 \pm 30.5$ & 39.0 & \pm 23.3 & 41.7 & \pm 17.1 \\
\hline Turbellaria & 4.0 & $\pm \quad 5.5$ & $1.7 \pm 0.8$ & 4.0 & \pm 2.3 & 5.8 & \pm 4.4 \\
\hline Ostracoda & 6.8 & \pm 4.4 & $4.5 \pm 1.9$ & 7.5 & \pm 4.4 & 9.7 & \pm 5.3 \\
\hline Copepoda & 0.5 & \pm 0.8 & $1.3 \pm 1.2$ & 2.0 & \pm 1.8 & 7.8 & \pm 8.6 \\
\hline p-meiofauna & 52.0 & \pm 14.7 & $77.2 \pm 30.4$ & 53.3 & \pm 27.8 & 65.2 & \pm 31.3 \\
\hline Hydrobia ulvae & & & & 3.7 & \pm 2.5 & 9.2 & \pm 4.8 \\
\hline
\end{tabular}

Table 3

Enclosure experiment with large cages: 25 Pomatoschistus microps, 16.-19. 8. 1977, did not feed on meiofauna. The high abundance of ostracods in the control is probably due to extreme patchiness. Small annelids, particularly juvenile Scoloplos armiger, were significantly decimated. 12 Nephtys hombergi, 29. 8.-1. 9. 1977, had no effect on meiofauna

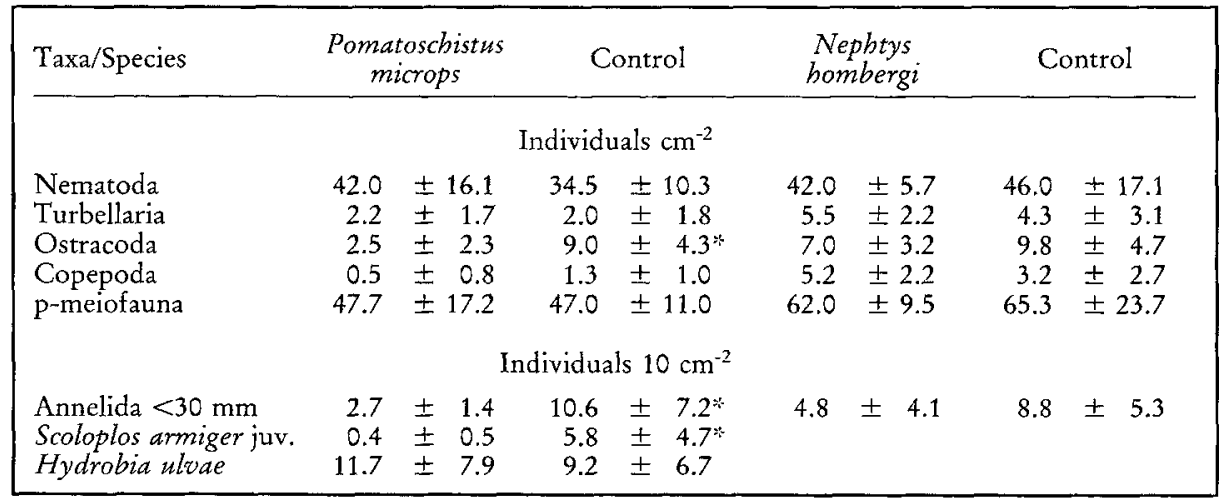


Nephtys hombergi Savigny, Nereis diversicolor O. F. Müller, Anaitides mucosa (Oersted), Eteone longa (Fabr.); one nemertine, Lineus viridis (Fabr.) Johnston; four crustaceans, Gammarus locusta (L.), Crangon crangon (L.), Carcinus maenas (L.), Pagurus bernhardus (L.) with and without colonies of Hydractinia echinata (Fleming) on its shells; and a fish, Pomatoschistus microps (Kröyer).

Five of these species did not alter meiofaunal abundance within cages: $A$. mucosa, $E$. longa, N. hombergi, G. locusta, and P. microps (Tables 2 and 3). G. locusta does not seem to be a predator on meiofaunal organisms. $A$. mucosa preyed on small members of the macrofauna, particularly on juvenile hydrobiids. Only 65 annelids $<30 \mathrm{~mm}$ length survived in their cage as compared with 102 in the control cage. Meiofaunal abundance was somewhat lower in all major taxa but not significantly. P. microps preyed heavily on small annelids, particularly on those living close to the sediment surface, but not on meiofauna. However, this experiment was inappropriate to demonstrate predation on copepods since numbers in both cages were too low. The abundance of Ostracoda in the control cage was unusually high and statistical significance is probably not related to predation. $N$. bombergi is a voracious predator on adult Scoloplos armiger (O. F. Müller), an abundant bacterivorous polychaete. In this experiment, numbers were 11 in the predator cage while 37 still lived in the control. Predation on small sized annelids was not significant and there were no

Table 4

Enclosure experiment with large cages: 12 Nereis diversicolor, 27.-30. 7. 1978, preyed significantly on nematodes, turbellarians and juvenile cockles. Lineus viridis, 5.-8. 9. 1978, lowered abundances of nematodes, copepods and probably of turbellarians

\begin{tabular}{|c|c|c|c|c|c|}
\hline Taxa/Species & $\begin{array}{c}\text { Nereis } \\
\text { diversicolor }\end{array}$ & Control & $\begin{array}{c}\text { Lineus } \\
\text { viridis } \\
16\end{array}$ & $\begin{array}{l}\text { Lineus } \\
\text { viridis } \\
8\end{array}$ & Control \\
\hline \multicolumn{6}{|c|}{ Individuals $\mathrm{cm}^{-2}$} \\
\hline Nematoda & $\begin{array}{c}80.0 \\
\pm 33.7\end{array}$ & $\begin{array}{l}191.2 \\
\pm 43.0 *\end{array}$ & $\begin{array}{c}43.7 \\
\pm 10.0\end{array}$ & $\begin{array}{c}44.8 \\
\pm 8.6\end{array}$ & $\begin{array}{c}63.3 \\
\pm 6.5^{*}\end{array}$ \\
\hline Turbellaria & $\begin{array}{r}6.0 \\
\pm 3.3\end{array}$ & $\begin{array}{c}19.8 \\
\pm 11.1 \%\end{array}$ & $\begin{array}{c}3.8 \\
\pm 3.8\end{array}$ & $\begin{array}{c}6.5 \\
\pm 4.8\end{array}$ & $\begin{array}{r}6.3 \\
+2.1\end{array}$ \\
\hline Ostracoda & $\begin{array}{r}13.2 \\
\pm 6.8\end{array}$ & $\begin{array}{l}21.2 \\
\pm 9.7\end{array}$ & $\begin{array}{c}3.2 \\
\pm 2.3\end{array}$ & $\begin{array}{l}2.8 \\
\pm 2.5\end{array}$ & $\begin{array}{r}2.3 \\
\pm 1.6\end{array}$ \\
\hline Copepoda & $\begin{array}{c}28.5 \\
\pm 16.4\end{array}$ & $\begin{array}{c}33.5 \\
\pm 12.3\end{array}$ & $\begin{array}{c}4.3 \\
\pm 4.2\end{array}$ & $\begin{aligned} & 4.8 \\
\pm & 2.9\end{aligned}$ & $\begin{array}{c}10.7 \\
\pm 4.0 *\end{array}$ \\
\hline p-meiofauna & $\begin{array}{c}129.0 \\
\pm 23.5\end{array}$ & $\begin{array}{c}270.0 \\
\pm 64.8\end{array}$ & $\begin{array}{c}55.2 \\
\pm 14.3\end{array}$ & $\begin{array}{c}59.0 \\
\pm 13.4\end{array}$ & $\begin{array}{c}84.5 \\
\pm 11.2^{*}\end{array}$ \\
\hline Hydrobia ulvae & $\begin{array}{r}15.3 \\
\pm 8.8\end{array}$ & $\begin{array}{c}17.3 \\
\pm \quad 4.5\end{array}$ & $\begin{array}{l}11.3 \\
\pm 7.2\end{array}$ & $\begin{array}{l}15.2 \\
\pm \quad 5.7\end{array}$ & $\begin{array}{l}11.8 \\
+\quad 5.0\end{array}$ \\
\hline \multicolumn{6}{|c|}{ Individuals $10 \mathrm{~cm}^{-2}$} \\
\hline Cerastoderma edule $<5 \mathrm{~mm}$ & $\begin{array}{r}4.0 \\
\pm \quad 5.1\end{array}$ & $\begin{array}{c}13.5 \\
\pm 5.8^{*}\end{array}$ & $\begin{array}{l}3.0 \\
\pm 1.7\end{array}$ & $\begin{array}{c}2.8 \\
\pm 1.9\end{array}$ & $\begin{array}{c}3.3 \\
\pm 1.9\end{array}$ \\
\hline Annelida $<30 \mathrm{~mm}$ & $\begin{array}{c}23.2 \\
\pm 11.2\end{array}$ & $\begin{array}{c}25.5 \\
\pm 17.3\end{array}$ & $\begin{array}{c}4.3 \\
\pm 0.8\end{array}$ & $\begin{array}{c}7.0 \\
\pm 3.8\end{array}$ & $\begin{array}{c}7.2 \\
\pm 2.9\end{array}$ \\
\hline
\end{tabular}


losses in meiofauna. In an experiment with the phyllodocid $E$. longa, the control cage was mislaid. However, high abundance of meiofauna within the predator cage suggests no predation.

Table 5

Enclosure experiments: 80 juvenile Crangon crangon (10-15 mm length) in a large cage, 12.-15. 8. 1977 , preyed significantly on turbellarians and small annelids. In the control cage, 16 juvenile shrimp became enclosed unintentionally. 100 juvenile Carcinus maenas $(2-4 \mathrm{~mm}$ carapace width) in a small cage, 21.-25. 7. 1977. At the end of experiment only $47 \mathrm{crabs}$ were still alive (cannibalism). Crabs preyed most heavily on meiofauna and surface-dwelling small macrofauna. Results on the latter were obtained from six small cages where all the enclosed sediment was sampled

\begin{tabular}{|c|c|c|c|c|c|c|c|}
\hline Taxa/Species & \multicolumn{2}{|c|}{$\begin{array}{c}\text { Crangon } \\
\text { crangon }\end{array}$} & Control & \multicolumn{2}{|c|}{$\begin{array}{c}\text { Carcinus } \\
\text { maenas }\end{array}$} & \multicolumn{2}{|c|}{ Control } \\
\hline \multicolumn{8}{|c|}{ Individuals $\mathrm{cm}^{-2}$} \\
\hline Nematoda & 35.2 & \pm 13.1 & $34.5 \pm 10.3$ & 13.8 & \pm 8.1 & 95.0 & $\pm 39.1 \%$ \\
\hline Turbellaria & 0.2 & $\pm \quad 0.4$ & $2.0 \pm 1.8^{*}$ & 0.2 & \pm 0.4 & 12.7 & $\pm 6.1 \%$ \\
\hline Ostracoda & 6.2 & \pm 1.7 & $9.0 \pm 4.3$ & 5.0 & \pm 4.8 & 22.8 & $\pm 15.5^{*}$ \\
\hline Copepoda & 0.2 & \pm 0.4 & $1.3 \pm 1.0$ & 3.7 & \pm 5.2 & 10.3 & \pm 5.7 \\
\hline \multirow[t]{2}{*}{ p-meiofauna } & 42.2 & \pm 13.7 & $47.0 \pm 11.0$ & 22.8 & \pm 15.1 & 141.0 & $\pm 56.0 \%$ \\
\hline & \multicolumn{3}{|c|}{ Individuals $10 \mathrm{~cm}^{-2}$} & \multicolumn{4}{|c|}{ Individuals $83 \mathrm{~cm}^{-2}$} \\
\hline \multirow{3}{*}{$\begin{array}{l}\text { Hydrobia ulvae } \\
\text { Scoloplos armiger } \\
\text { juv. } \\
\text { Annelida }<30 \mathrm{~mm}\end{array}$} & 12.9 & \pm 9.7 & $12.9 \pm 7.8$ & 18.0 & \pm 11.3 & 190.7 & $\pm 54.2 *$ \\
\hline & 0.0 & 0.0 & $3.7 \pm 3.6^{*}$ & 13.3 & \pm 8.5 & 104.3 & $\pm 31.3 \%$ \\
\hline & 2.1 & \pm 2.1 & $12.1 \pm 9.4^{*}$ & 35.0 & \pm 17.6 & 134.3 & $\pm 34.9^{*}$ \\
\hline
\end{tabular}

$N$. diversicolor and $L$. viridis preyed on meiofauna (Table 4): the former on nematodes, turbellarians, and also on cockle spat, the latter on nematodes and copepods. Juvenile $C$. crangon preyed heavily on small annelids but of the meiofauna only turbellarians were significantly decimated (Table 5). Juvenile C. maenas, on the other hand, turned out to be voracious predators on almost all animals they could handle and which lived close to the sediment surface. A vertical survey on nematodes in the sediment showed that crabs caused losses only in the upper $5 \mathrm{~mm}$ of sediment (Table 6).

Table 6

Vertical distribution of Nematoda below $2 \mathrm{~cm}^{2}$ of the lugworm flat, under crab predation and when undisturbed, 21.-25. 7. 1977. Juvenile Carcinus maenas (2-4 mm carapace width) do not capture nematodes deeper than $5 \mathrm{~mm}$ in the sediment

\begin{tabular}{|ccc|}
\hline Depth $(\mathrm{mm})$ & Carcinus maenas cage & Control cage \\
\hline $0-5$ & 32 & 210 \\
$5-10$ & 50 & 61 \\
$10-15$ & 24 & 11 \\
$15-20$ & 15 & 17 \\
\hline
\end{tabular}




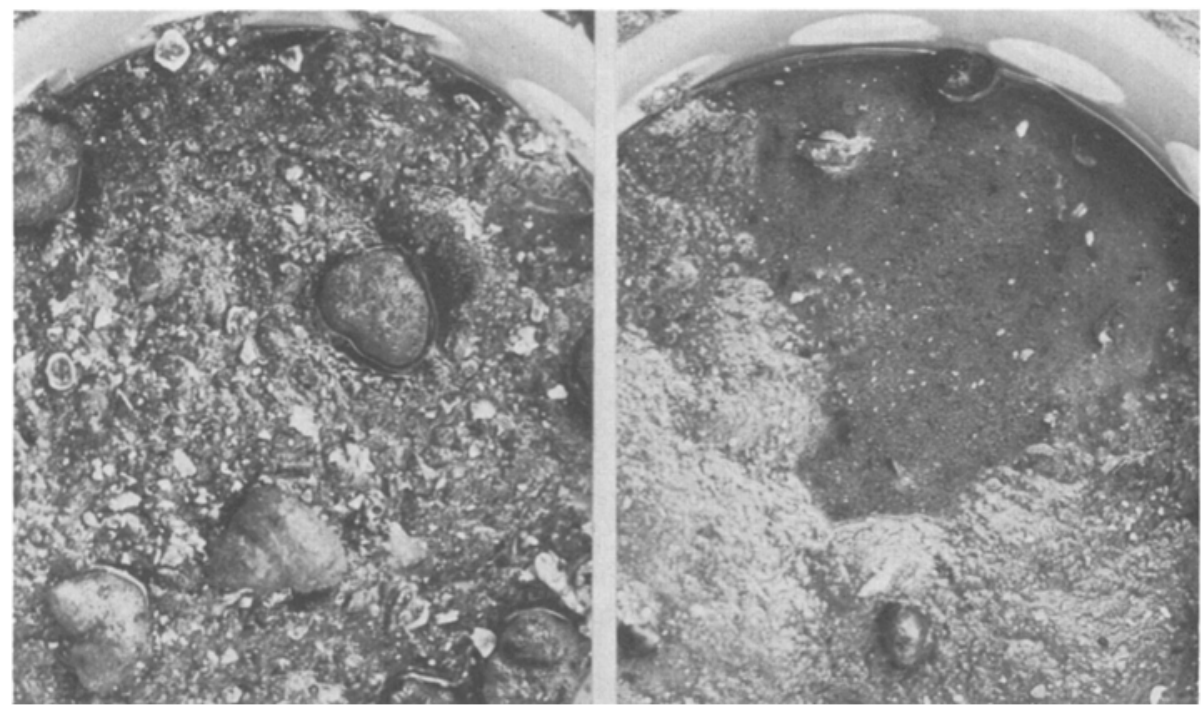

Fig. 2: Sediment surface after six tidal cycles in a cage with Pagurus bernhardus (left) and in a control cage. The hermit crabs reworked the sediment entirely which is indicated by abundant shell gravel on the surface. The hermit shells are overgrown with Hydractinia echinata

Table 7

Enclosure experiment with large cages: 10 Pagurus bernbardus, 28.-31. 8. 1978, significantly decimated nematodes and turbellarians; 8 hermit crabs, slightly bigger, with housings colonized by Hydractinia echinata, caused considerable losses in all meiofauna and some small annelids

\begin{tabular}{|c|c|c|c|c|c|c|}
\hline Taxa & $\begin{array}{r}H y c \\
e c h \\
P c \\
\text { ber }\end{array}$ & $\begin{array}{l}\text { Iractinia } \\
\text { inata on } \\
\text { agurus } \\
\text { nhardus }\end{array}$ & $\begin{array}{r}P_{a} \\
\text { bern }\end{array}$ & $\begin{array}{l}\text { gurus } \\
\text { bardus }\end{array}$ & & introl \\
\hline \multicolumn{7}{|c|}{ Individuals $\mathrm{cm}^{-2}$} \\
\hline Nematoda & 65.5 & \pm 25.2 & 124.5 & $\pm 39.8^{*}$ & 172.0 & $\pm 45.2 \%$ \\
\hline Turbellaria & 0.0 & & 1.5 & $\pm 1.2 \%$ & 7.8 & $\pm 4.7 *$ \\
\hline Ostracoda & 10.5 & \pm 5.4 & 19.5 & $\pm 6.9 \%$ & 28.0 & \pm 29.8 \\
\hline Copepoda & 3.7 & \pm 2.8 & 21.8 & $\pm 9.3^{*}$ & 30.7 & $\pm 11.2 *$ \\
\hline $\mathrm{p}$-meiofauna & 81.0 & \pm 31.3 & 170.0 & $\pm 42.4^{*}$ & 242.5 & $\pm 91.7 *$ \\
\hline \multicolumn{7}{|c|}{ Individuals $10 \mathrm{~cm}^{-2}$} \\
\hline Spio filicornis & 0.3 & \pm 0.5 & 3.2 & $\pm 2.2 *$ & 2.8 & $\pm 1.3^{*}$ \\
\hline Annelida $<30 \mathrm{~mm}$ & 6.3 & \pm 2.0 & 13.5 & $\pm 6.3 \%$ & 15.7 & $\pm 7.2 *$ \\
\hline
\end{tabular}

Juvenile $P$. bernhardus (average body volume $0.7 \mathrm{~cm}^{3}$ ) completely reworked the sediment within cages (Fig. 2). This predator/disturber caused significant losses in nematodes and turbellarians (Table 7). Hermit crabs, carrying $H$. echinata on their shells, caused considerably higher losses in all meiofauna and in some small polychaetes too. Losses in the tube-dwelling polychaete Spio filicornis (O. F. Müller) elucidate the method of predation. In petri dishes, this spionid readily starts to swim about when its tube is 
Table 8

Predator exclusion experiment with large cages: numbers of meiofauna are based on two cages each time since cages with $40 \mu \mathrm{m}$ and $1 \mathrm{~mm}$ mesh gauze did not show differences. Numbers of annelids are based on the $1 \mathrm{~mm}$ cages only. Predator cages, cages with uncovered lateral holes, and two uncaged sites served as controls. Meiofauna gained less from predator exclusion than did juvenile macrofauna

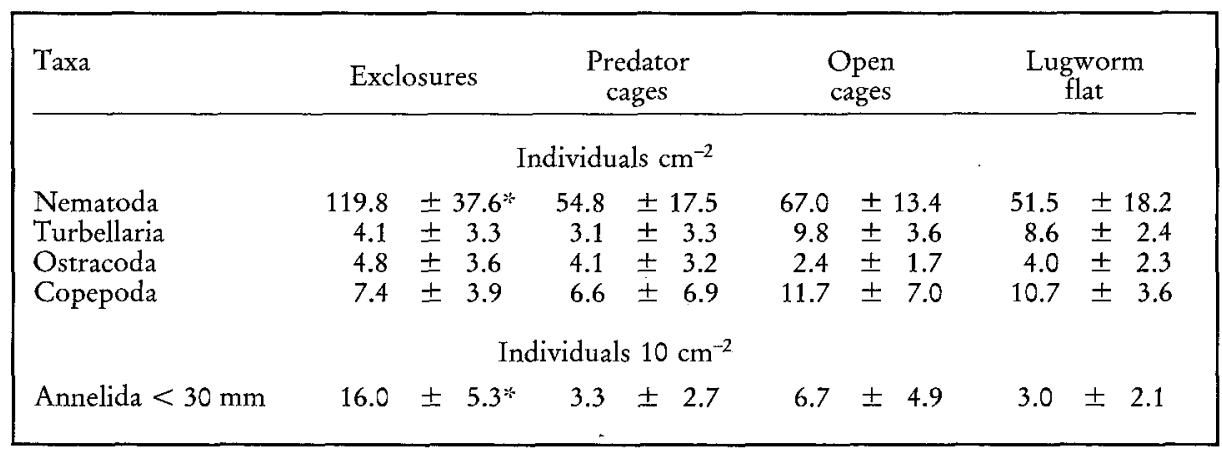

touched with a needle. Other spionids retract into their tube when touched. The digging hermits disturb S. filicornis, which starts to swim and finally ends up in the tentacles of the polyps. Most likely, meiofauna suffers a similar fate.

The predator exclusion experiment was run from 17. 8. to 19. 10. 1977 (64 days). No significant differences in meiofaunal abundances could be observed between $40 \mu \mathrm{m}$ and 1 $\mathrm{mm}$ mesh cages. In Table 8 , both are combined and means refer to $\mathrm{n}=12$ samples. Immigration of juvenile macrofauna was blocked by the $40 \mu \mathrm{m}$ gauze. To present comparable counts, numbers of macrofauna in Table 8 refer to $1 \mathrm{~mm}$ cages only. In the two predator exclosures, nematode abundance was about twice as high as in all other cages and the uncaged flat. Other meiofauna did not show any significant differences between cages. Juveniles of the macrofauna, on the other hand, increased to about 5 times the density of the control sites. Twenty-eight small cockles ( $<10 \mathrm{~mm}$ length) were found in the exclosures but none in the controls.

\section{DISCUSSION AND CONCLUSIONS}

The trophic role of the meiofauna in marine ecosystems is insufficiently known. Inferences based on gut content analyses, abundance and productivity estimates, as well as on population dynamics produced rather diverging results. Recently, Bell \& Coull (1978) conducted an experiment with shrimp as predators and meiofauna as prey. They concluded that shrimp are capable of "regulating meiofauna"; however, it still had to be shown that shrimp really alter meiofaunal abundance significantly out in the sea. This step is included in the present experiments by protecting meiofauna from the natural set of potential predators belonging to the macrofauna. The capability of some macrobenthic species from tidal flats to prey heavily on meiofauna is confirmed, but it is concluded that their overall predation pressure exerted on meiofauna is only moderate and that meiofauna is secondrate prey. 
First, the present results on prey selection are compared with literature data. Gammarus locusta does not prey on members of meiofauna. Other species of the genus have been shown to be detritus feeders (Gable \& Croker, 1977; Harrison, 1977; Kostalos \& Seymour, 1976). Rasmussen (1973) mentioned Anaitides mucosa as an important predator on many small invertebrates. This is confirmed with the specification that permanent meiofauna is not included. Carnivorous scavenging also occurs in this polychaete (Reise, 1979). Behrends \& Michaelis (1977) observed Eteone longa attacking the polychaete Scolelepis squamata (Müller). This prey does not occur on the lugworm flat and no alternative was observed.

Nephtys hombergi preys on large worms (Clark, 1962), and particularly on adult Scoloplos armiger (Reise, unpubl.). Based on productivity calculations, Warwick \& Price (1975) predicted that $N$. hombergi would also prey on meiofauna. In the enclosures, it consumed only large food items. In the gut of Pomatoschistus microps, Healy (1972) found mainly amphipods and some benthic copepods. The present experiments did not reveal predation on permanent meiofauna, but the capture of small annelids was noted.

Nereis diversicolor is omnivorous and the prey spectrum includes meiofauna (Bilio, 1967; Goerke, 1971; Perkins, 1958 cit. in McIntyre, 1969). Calculated from the enclosure experiment, each $N$. diversicolor swallowed about 900 nematodes per day, roughly equal to 19 Joules (see Hansen, 1978). This amounts to some $5 \%$ of its own calorific content and may represent a quarter of its daily demand. Cantell (1975) observed a $1 \mathrm{~cm}$ long Lineus viridis swallowing a polychaete of similar length. In my experiments, L. viridis preyed on some meiofauna but not on macrofauna. The quantity consumed remained small and $I$ doubt that meiofauna was the only prey.

The stomach of $C$. crangon contains, besides larger prey, Copepoda, Ostracoda and Nematoda (Plagmann, 1939). Gerlach \& Schrage (1969) reared C. crangon on a nematode diet which kept the shrimp alive but growth was retarded. Shrimp in the short term enclosure preyed on macrobenthos and on turbellarians. In a control cage of the exclosure experiment (64 days), shrimp also preyed on nematodes.

Early benthic stages of Carcinus maenas preyed most heavily on all meiofauna. From individual energy budgets of O-group C. maenas Eriksson \& Edlund (1977) inferred that these crabs are micro-carnivores. According to Klein Breteler (1975), an individual crab of moulting stage III consumes 12 Joules per day; this corresponds to some 560 nematodes. On average, calculated from the enclosure experiment, each crab caught no more than 24 nematodes per day and did not leave many alive. Thus, feeding exclusively on such small prey is no way to meet daily energy demands. Predation on juvenile macrofauna is indispensable for these little crabs. Similarly, Bregnballe (1961) calculated that young plaice cannot cover food requirements when feeding exclusively on benthic copepods. Small annelids were the indispensable food.

Pagurus bernbardus is omnivorous (Gerlach et al., 1976). In the enclosures, hermits reworked the sediment entirely and predation could not be separated from general disturbances. However, Hydractinia echinata does not cause additional disturbances and the heavy meiofaunal losses in the Pagurus + Hydractinia cage can safely be attributed to predation by the hydrozoan colony. A detailed account on the food of $H$. echinata colonies is given by Christensen (1967). Nematodes are the main prey.

In the Wadden Sea, $H$. echinata rarely occurs anywhere else than on gastropod shells 
occupied by hermits. Most likely colonies are dependent on the digging activities of $P$. bernhardus to obtain sufficient meiobenthic food, while hermit crabs benefit because the polyp colonies enlarge the shell. This mutualism helps the hermit to postpone changes in residence without suffering growth limitations, and the bottleneck of mediumsized shells in the Wadden Sea is overcome.

There are other macrobenthic predators in the Wadden Sea which, according to the literature, may prey on meiofauna: young flatfish and a few other small fish, Praunus flexuosus O. F. Müller, and Harmothoe sarsi (Klingberg). None was abundant on the lugworm flat.

What is the overall importance of macrobenthic predators to meiofauna? $N$. diversicolor sometimes occurs in very dense populations. On a sandy flat, 4-6 cm long worms with individual surface territories of only $4 \mathrm{~cm}^{2}$ were observed (Reise, 1979). A striking negative spatial correlation between a $N$. diversicolor population of similar density and meiofauna (Nematoda, Copepoda) has been described by Rees (1940). Young P. bernhar$d u s$ are numerous in the lower intertidal where mussel banks and shell gravel provide shelter. The adults remain subtidally in similar habitats. In these limited areas, the twosome predators - hermit and polyp - decimate meiofauna considerably.

The very early benthic stages of plaice $(12 \mathrm{~mm})$, shrimp $(6 \mathrm{~mm})$, and shore crabs $(1.5$ mm width) start with feeding on meiobenthic prey. On a mud flat between mussel banks up to two juveniles $10 \mathrm{~cm}^{-2}$ were found in July (Reise, 1977); meiofauna probably suffered high mortality. However, because of rapid growth in these juveniles, they shift to larger prey within a few days.

Based on the predator exclusion experiment and the above considerations, I conceive the permanent meiofauna of the Wadden Sea to be only locally and temporarily "grazed down" by macrobenthos. The overall predation pressure is comparatively moderate. Bell (in prep.) excluded macroepifauna in a high intertidal Spartina marsh and observed no increase in nematode abundance. Copepods showed "peak" response curves. For the latter she assumes "frequency dependent processes which operated in the absence of macroepifauna influence". This is contrasted by the high predation pressure exerted on juvenile macrofauna in shallow waters (Reise, 1977, 1978; Virnstein, 1977). Bregnballe (1961) found that permanent meiofauna (Harpacticoida, Ostracoda, Nematoda) could not have been significantly decimated by young plaice in a shallow fjord, while small annelids, particularly Paranais litoralis, were severely exploited.

What are the alternative regulators of meiofaunal abundance if predation pressure exerted by macrobenthos is ruled out?

(1) Meiofaunal predators may regulate numbers of all other meiofauna. In that case, only the fate of the top predators should be linked to other factors. The Turbellaria include many of the top predators, and in the enclosures, they suffered severe predation from shrimp, crabs and $N$. diversicolor. Heip \& Smol (1975) observed a classic predator-prey interaction between Protobydra leuckarti Greef and a harpacticoid copepod in a brackish lagoon. The hypothesis of "severe internal predation" seems to be worth future research.

(2) Physical factors and food limitations are other alternatives. In many Wadden Sea habitats, these factors are modified by macrobenthic deposit feeders via habitat conditioning. While accidental consumption of meiofauna by large sediment swallowers is very low (Hansen, 1978; Reise \& Ax, 1979), their sediment reworking activity does affect meio- 
faunal abundance considerable. In a preliminary experiment, the lugworm Arenicola marina (L.) was excluded from a $2 \mathrm{~m}^{2}$ plot. Relative to a control site with 90 lugworms, nematode abundance decreased by $40 \%$ within 20 days. In the lagoon mentioned above, Heip (1976) found no incidence of predation on the ostracod Cyprideis torosa (Jones) and concludes that "regulation of numbers is probably not external and may be a function of the past of the habitat".

Any combination of these suggested processes may regulate meiofaunal abundance locally. At present a sole overriding master factor seems rather unlikely. Probably, trophic links are just as diverse as taxonomic composition in meiofauna.

Acknowledgements. I thank Professor O. Kinne and the staff of the Biologische Anstalt Helgoland for kindly providing laboratory space and technical support at the Litoralstation List/Sylt. Cages were constructed by Mr. E. Jordan and Mrs. D. Bürger processed the photographs.

\section{LITERATURE CITED}

Behrends, G. \& Michaelis, H., 1977. Zur Deutung der Lebensspuren des Polychaeten Scolelepis squamata. Senckenberg. marit. 9, 47-57.

Bell, S. S. \& Coull, B. C., 1978. Field evidence that shrimp predation regulates meiofauna. Oecologia $35,141-148$.

Bilio, M., 1967. Nahrungsbeziehungen der Turbellarien in Küstensalzwiesen. Helgoländer wiss. Meeresunters. 15, 602-621.

Bregnballe, F., 1961. Plaice and flounder as consumers of the microscopic bottom fauna. Meddr Danm. Fisk.-og. Havunders. 3, 133-182.

Cantell, C.-E., 1975. Anatomy, taxonomy, and biology of some scandinavian heteronemertines of the genera Lineus, Micrura, and Cerebratulus. Sarsia 58, 89-122.

Christensen, H. E., 1967. Ecology of Hydractinia echinata (Fleming) (Hydroidea, Athecata) I. Feeding biology. Ophelia 4, 245-275.

Clark, R. B., 1962. Observations on the food of Nephtys. Limnol. Oceanogr. 7, 380-385.

Elmgren, R., 1976. Baltic benthos communities and the role of the meiofauna. Contr. Askö Lab. 14, $1-31$.

Eriksson, S. \& Edlund, A.-M., 1977. On the ecological energetics of O-group Carcinus maenas (L.) from a shallow sandy bottom in Gullmar Fjord, Sweden. J. exp. mar. Biol. Ecol. 30, 233-248.

Gable, M. F. \& Croker, R. A., 1977. The salt marsh amphipod Gammarus palustris Bousfield, 1969 at the northern limit of its distribution. I. Ecology and life cycle. Estuar. coast. mar. Sci. 5, 123-134.

Gerlach, S. A., 1978. Food-chain relationships in subtidal silty sand marine sediments and the role of meiofauna in stimulating bacterial productivity. Oecologia 33, 55-69.

- Ekstrøm, D. K. \& Eckardt, P. B., 1976. Filter feeding in the hermit crab, Pagurus bernhardus. Oecologia 24, 257-264.

— \& Schrage, M., 1969. Freilebende Nematoden als Nahrung der Sandgarnele Crangon crangon. Experimentelle Untersuchungen über die Bedeutung der Meiofauna als Nahrung für das marine Makrobenthos. Oecologia 2, 362-375.

Goerke, H., 1971. Die Ernährungsweise der Nereis-Arten (Polychaeta, Nereidae) der deutschen Küsten. Veröff. Inst. Meeresforsch. Bremerh. 13,1-50.

Hansen, M. D., 1978. Nahrung und Freßverhalten bei Sedimentfressern dargestellt am Beispiel von Sipunculiden und Holothurien. Helgoländer wiss. Meeresunters. 31, 191-221.

Harrison, P. G., 1977. Decomposition of macrophyte detritus in sea-water: Effects of grazing by amphipods. Oikos 28, 165-169.

Healy, M. C., 1972. On the population ecology of the common goby in the Ythan estuary. J. nat. Hist. 6, 133-145. 
Heip, C., 1976. The life-cycle of Cyprideis torosa (Crustacea, Ostracoda). Oecologia 24, 229-245.

- \& Smol, N., 1976. On the importance of Protobydra leuckarti as a predator on meiobenthic populations. In: proceedings of the 10th European symposium on marine biology. Ed. by G. Personne \& E. Jaspers. Universa Press, Wettern, 2, 285-296.

Klein Breteler, W. C. M., 1975. Food consumption, growth and energy metabolism of juvenile shore crabs, Carcinus maenas. Neth. J. Sea Res. 9, 255-272.

Kostalos, M. \& Seymour, R. L., 1976. Role of microbial enriched detritus in the nutrition of Gammarus minus (Amphipoda). Oikos 27, 512-516.

McIntyre, A. D., 1969. Ecology of marine meiobenthos. Biol. Rev. 44, 245-290.

Muus, B. J., 1967. The fauna of Danish estuaries and lagoons. Meddr Danm. Fisk.-og. Havunders. 5, $1-316$.

Plagmann, J., 1939. Ernährungsbiologie der Garnele (Crangon vulgaris F.). Helgoländer wiss. Meeresunters. 2, 113-162.

Rasmussen, E., 1973. Systematics and ecology of the Isefjord marine fauna. Ophelia 11, 1-507.

Rees, C. B., 1940. A preliminary study of the ecology of a mudflat. J. mar. biol. Ass. U. K. 24, 185-199.

Reise, K., 1977. Predator exclusion experiments in an intertidal mud flat. Helgoländer wiss. Meeresunters. 30, 263-271.

- 1978. Experiments on epibenthic predation in the Wadden Sea. Helgoländer wiss. Meeresunters. 31, 55-101.

- 1979. Spatial configurations generated by motile benthic polychaetes. Helgoländer wiss. Meeresunters. 32, 55-72.

- \& Ax, P., 1979. A meiofaunal "thiobios" limited to the anaebic sulfide system of marine sand does not exist. Mar. Biol. (In press).

Sachs, L., 1971. Statistische Auswertungsmethoden. Springer, Berlin, 545 pp.

Smidt, E. L. B., 1951. Animal production in the Danish Waddensea. Meddr Danm. Fisk.-og. Havunders. 11, 1-151.

Virnstein, R. W., 1977. The importance of predation by crabs and fishes on benthic infauna in Chesapeake Bay. Ecology 58, 1199-1217.

Warwick, R. M. \& Price, R., 1975. Macrofauna production in an estuarine mud-flat. J. mar. biol. Ass. U. K. 55, 1-18.

Wohlenberg, E., 1937. Die Wattenmeer-Lebensgemeinschaften im Königshafen von Sylt. Helgoländer wiss. Meeresunters. 1, 1-92. 